\title{
Synthesis and Antitumor Activity of Poly(L-cysteine) Bonded Covalently 5-Fluorouracil
}

\author{
Fushun YANG* and Renxi ZHUO \\ Department of Chemistry, Wuhan University, \\ Wuhan 430072, People's Republic of China
}

(Received January 5, 1990)

\begin{abstract}
Poly(L-cysteine) linked covalently 5-fluorouracil was prepared. Hydrolytic release of 5-fluorouracil in alkali and neutral media, and antitumor activity of these new polymeric drugs against Ehrlich ascites carcinoma in vitro and in vivo were studied.

KEY WORDS Polymeric Carrier Drug / Antitumor Activity / 5-Fluorouracil /
\end{abstract}

The medicinal chemists often use the term "prodrug" in their literatures. It normally means a biologically active unit that is covalently combined with a physiologically inactive segment. The prodrug, after administration into the system, undergo enzymatic degradation or hydrolysis leading to the generation of the original pharmacon which can then react with the receptor. The latent potentiality of this type of drug has not been fully exploited and perhaps polymer carrier drugs with many facets similar to prodrugs may be developed. In polymeric carrier drugs, the physiological response that is normally observed is primarily due to the reaction of the active pharmacon, released via enzymatic hydrolysis or degradation, at the appropriate receptor site.

Very recently, a great deal of interest has centered on the idea of utilizing biocompatible polymers to regulate the delivery of pharmaceuticals and veterinary drugs. So far, a number of polymer-controlled drug delivery systems have been successfully developed to control the rate of drug administration and prolong the duration of therapeutic action as well as to target the delivery of drugs. Poly(amino acid)s have been used as polymeric carriers to prepare controlled delivery systsms, due to their biocompatibility and biodegradable feature.

5-Fluorouracil (5-FU) possess good antitumor activity, but has significantly high toxic side effects. It was reported that 5-FU was covalently linked with poly(L-lysine $)^{1}$ and poly(L-tyrosine $)^{2}$ as a means of achieving increased drug uptake by tumor cells and reducing its side effects. In this paper, a series of poly(L-cysteine) (polyCysH) attached 5-FU were prepared in order to retrict the concentration of the drug agent to a narrow range to elicit the desired medical activity while reducing potentially dangerous side effects. The hydrolysis studies in various media, as expected, showed that the polyCysH linked 5-FU via an amide link could release the corresponding drug agent, but those via a $\mathrm{C}-\mathrm{N}$ bond could not. Furthermore, the polymeric drugs which can release 5-FU have better antitumor activity against Ehrlich ascites carcinoma.

* To whom all correspondence should be addressed. 


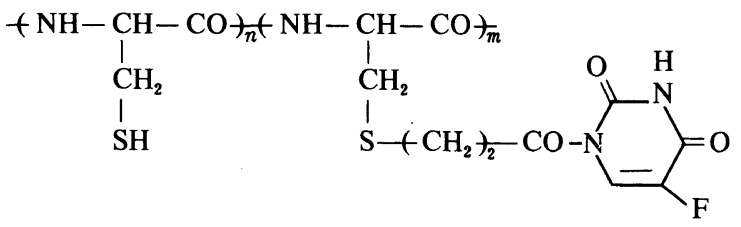<smiles>N#CC(CS)C(=O)NC(CSC(=O)n1cc(F)c(=O)[nH]c1=O)C(=O)O</smiles><smiles>[Y]=C=NCC(CS)C(=O)NC(CSCCNC(=O)O)C(=O)O</smiles>

\section{EXPERIMENTAL}

\section{Reagents and Instruments}

L-Cysteine was biochemical reagent. 1-(3Bromopropionyl)-5-fluorouracil(a), ${ }^{3}$ 1-chlorocarbonyl-5-fluorouracil(b), ${ }^{4}$ 1-(4-bromobutyl)5-fluorouracil(c) ${ }^{5}$ and 1-(6-bromohexyl)-5-fluorouracil(d) ${ }^{5}$ were prepared according to reported methods. All other reagents were of AR grade and away off oxygen with ultrasonic waves.

Elemental analysis were determined with Carlo Erba Elemental Analyzer modle 1106. IR spectra were recorded on a Nicolet 170 sx Spectrometer. UV spectra were run with a Shimadzu UV-240 Spectrometer. ${ }^{1} \mathrm{H}$ NMR spectra were recorded on a Varian EM-360L instrument. The number-average molecular weight of polyCysH was determined with the method of VPO on Knauer Osmometer.

\section{Synthesis}

Poly(L-cysteine). To a solution of $S$-carbobenzoxy- $N$-carboxy-L-cysteine anhydride ${ }^{6}(8.0$ g) in dry benzene $(150 \mathrm{ml})$ was added dieth- ylamine $(1.0 \mathrm{ml}$, of a $1 \% \mathrm{w} / \mathrm{v}$ solution in benzene) and the mixture kept at $50^{\circ} \mathrm{C}$ for $48 \mathrm{~h}$. Moisture was excluded by means of a calcium chloride tube, and then petroleum ether $(700 \mathrm{ml})$ was added and the polymer was collected, washed with petroleum ether and dried in vacuo, yield $6.2 \mathrm{~g}(94 \%)$.

Anal. Calcd. for $\left(\mathrm{C}_{11} \mathrm{H}_{11} \mathrm{NO}_{3} \mathrm{~S}\right)_{n}: \mathrm{C}, 55.70 \%$; $\mathrm{H}, 4.64 \%$; N, $5.91 \%$, Found: C, $55.67 \%$; , $4.70 \% ; \mathrm{N}, 6.05 \%$.

Poly $(S$-carbobenzoxy-L-cysteine) (5.6 g) prepared as above in liquid ammonia $(500 \mathrm{ml})$, finely cut sodium $(3.5 \mathrm{~g})$ was added in small portions with magnetic stirring. After three hours, the ammonia was allowed to evaporate and the residue was dissolved in air-free water. The aqueous solution was washed with ether and acidified with a few drops of concentrated hydrochloric acid. The poly(L-cysteine) which separated was collected by filtration under nitrogen pressure, washed with air-free water, and dried in a stream of nitrogen over phosphorus pentoxide, yield $1.4 \mathrm{~g}(58 \%)$. The number-average molecular weight was $2 \times 10^{3}$ $\left(\mathrm{PC}_{1}\right)$.

Anal. Calcd. for $\left(\mathrm{C}_{3} \mathrm{H}_{5} \mathrm{NOS}\right)_{n}$ : C, $34.05 \%$; 
$\mathrm{H}, 4.85 \%$; N, $13.59 \%$, Found: C, $35.02 \%$; $4.97 \% ; \mathrm{N}, 13.61 \%$.

Poly(L-cysteine) with molecular weight $3.1 \times$ $10^{4}\left(\mathrm{PC}_{2}\right)$ and $5.6 \times 10^{4}\left(\mathrm{PC}_{3}\right)$ were prepared as above-metioned method by adding $0.5 \mathrm{ml}$ and $0.2 \mathrm{ml}$ diethylamine $(1 \% \mathrm{w} / \mathrm{v}$ solution in benzene) into the polymerization solution of $S$-carbobenzoxy- $N$-carboxy-L-cysteine anhydride, respectively.

Poly(L-cysteine) containing 5-FU ( $\mathrm{PC}_{1 \mathrm{a}}$ as an example) PolyCysH (0.3 g) and 1-(3bromopropionyl)-5-fluorouracil (1.5 g) were added to oxygen-free pyridine $(20 \mathrm{ml})$. The mixture was kept at $50^{\circ} \mathrm{C}$ for $8 \mathrm{~h}$ with magnetic stirring, then concentrated to about $10 \mathrm{ml}$ in vacuo on a rotatory evaporator. To the residue was added $50 \mathrm{ml}$ of petroleum ether. A precipitate was collected by filtration, washed with water, acetone and petroleum ether, dried under reduced pressure, yield $0.64 \mathrm{~g}(63.0 \%$, calculated in conversion of $\mathrm{S}-\mathrm{H}$ group).

\section{Hydrolysis Studies}

Hydrolytic release of 5-FU from its matrix was determined by the measurement of UV absorbance of the polymeric drug solution in $267 \mathrm{~nm}$ at $37^{\circ} \mathrm{C}$ at regular interval, compared with the standard line of 5-FU in the same solvent. The results are shown in Figures 4-6.

\section{RESULTS AND DISCUSSION}

Table I shows that the conversion of S-H group, calculated from the nitrogen content analysis, is identical with corresponding reaction yield, which presents a substitution between $\mathrm{S}-\mathrm{H}$ group in polyCysH and 5-FU derivatives. From Figure 1, it is clear that UV

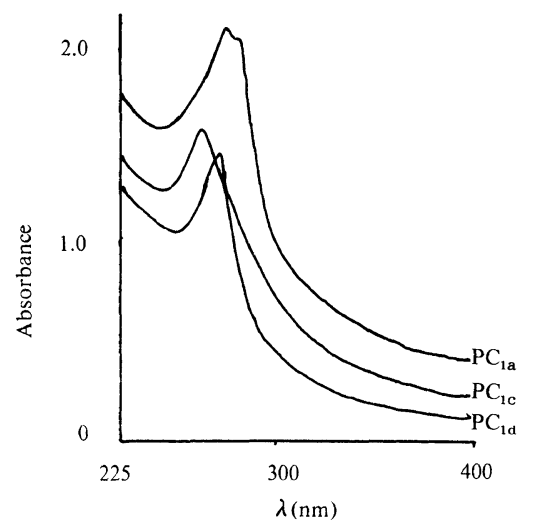

Figure 1. UV absorption of polyCys-5-FU conjugates (solvent, DMSO; conc, $0.0010 \mathrm{~g} / \mathrm{ml}$; temp, $25^{\circ} \mathrm{C}$ ).

Table I. Relation of S-H conversion to reaction conditions and molecular weight of polyCysH

\begin{tabular}{|c|c|c|c|c|c|c|c|}
\hline \multirow{2}{*}{ No. } & \multirow{2}{*}{$\begin{array}{c}\text { MW of } \\
\text { polyCysH } \\
\left(\times 10^{3}\right)\end{array}$} & \multirow{2}{*}{$\begin{array}{c}\text { Deriv. } \\
\text { of } \\
5-\mathrm{FU}\end{array}$} & \multicolumn{3}{|c|}{ Reaction conditions } & \multirow{2}{*}{$\frac{\text { Yield }}{\%}$} & \multirow{2}{*}{$\begin{array}{c}\begin{array}{c}\mathrm{S}-\mathrm{H} \\
\text { conversion }^{\mathrm{b}}\end{array} \\
\%\end{array}$} \\
\hline & & & $R^{\mathrm{a}}$ & $T /{ }^{\circ} \mathrm{C}$ & $t / \mathrm{h}$ & & \\
\hline $\mathrm{PC}_{1 \mathrm{a}}$ & 2.0 & $\mathrm{a}$ & 2 & 50 & 8 & 63.7 & 64.2 \\
\hline $\mathrm{PC}_{2 \mathrm{a}}$ & 31 & $\mathrm{a}$ & 2 & 50 & 8 & 60.6 & 60.8 \\
\hline $\mathrm{PC}_{3 \mathrm{a}}$ & 56 & $\mathrm{a}$ & 2 & 50 & 8 & 54.3 & 55.0 \\
\hline $\mathrm{PC}_{1 \mathrm{~b}}$ & 2.0 & b & 1 & 40 & 6 & 89.5 & 89.7 \\
\hline $\mathrm{PC}_{2 \mathrm{~b}}$ & 31 & b & 1 & 40 & 6 & 85.7 & 86.1 \\
\hline $\mathrm{PC}_{3 \mathrm{~b}}$ & 56 & b & 1 & 40 & 6 & 79.9 & 80.4 \\
\hline $\mathrm{PC}_{1 \mathrm{c}}$ & 2.0 & $\mathrm{c}$ & 2 & 50 & 8 & 53.6 & 54.3 \\
\hline $\mathrm{PC}_{2 \mathrm{c}}$ & 31 & $\mathrm{c}$ & 2 & 50 & 8 & 49.1 & 50.2 \\
\hline $\mathrm{PC}_{3 \mathrm{c}}$ & 56 & $\mathrm{c}$ & 2 & 50 & 8 & 46.8 & 47.0 \\
\hline $\mathrm{PC}_{1 \mathrm{~d}}$ & 2.0 & $\mathrm{~d}$ & 2 & 50 & 8 & 47.6 & 48.2 \\
\hline $\mathrm{PC}_{2 \mathrm{~d}}$ & 31 & d & 2 & 50 & 8 & 45.3 & 45.6 \\
\hline $\mathrm{PC}_{3 \mathrm{~d}}$ & 56 & d & 2 & 50 & 8 & 40.7 & 41.0 \\
\hline
\end{tabular}

a Ratio of moles of 5-FU derivatives to moles of $\mathrm{L}$-cysteine unit in polyCysH.

${ }^{b}$ Calculated from the data of nitrogen content analysis. 


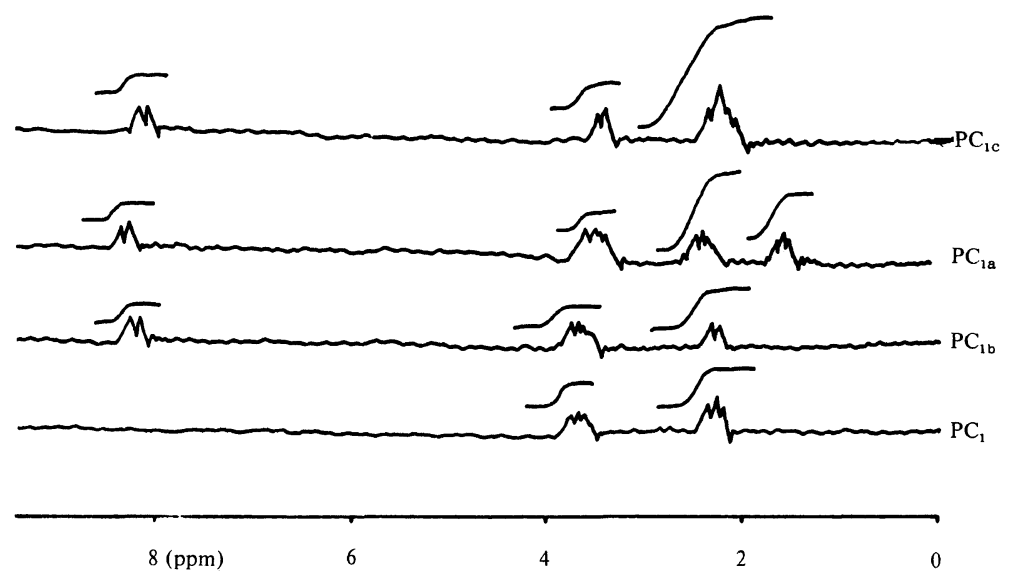

Figure 2. ${ }^{1} \mathrm{H}$ NMR of polyCysH and polyCys-5-FU conjugates $\left(\mathrm{F}_{3} \mathrm{CCO}_{2} \mathrm{H}\right)$.

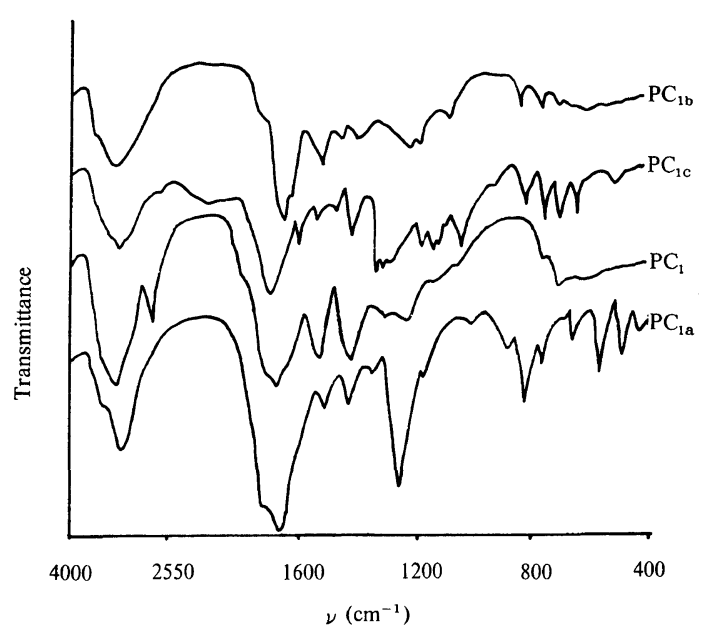

Figure 3. IR spectra of polyCysH and polyCys-5-FU conjugates $(\mathrm{KBr})$.

absorption peaks of aromatic rings appear at about $267 \mathrm{~nm}$, and from Figure 2, the chemical shift $(8.25 \mathrm{ppm})$ of hydrogen on $\mathrm{C}_{6}$ in $5-\mathrm{FU}$. In addition, the absorption peaks at $1680 \mathrm{~cm}^{-1}$ become significantly strengthened and those at $2550 \mathrm{~cm}^{-1}$ (S-H stretched responance) weakened in IR of polyCysH-5-FU conjugates compared with that of polyCysH.

Figures 4-6 show the delivery of 5-FU from its matrix in alkali and neutral media. As expected, hydrolytic rate of 5-FU from polyCysH-5-FU conjugates via an amide link

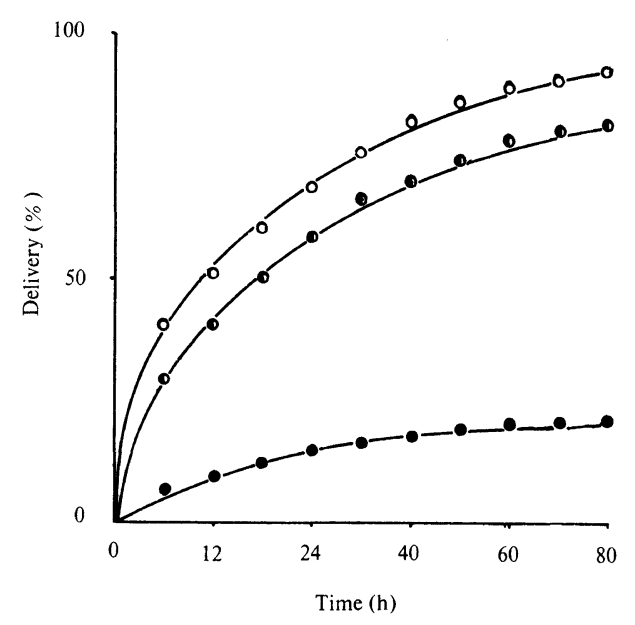

Figure 4. Hydrolytic delivery of 5-FU from polymeric drugs at $37^{\circ} \mathrm{C}$ and $\mathrm{pH} 9\left(\mathrm{O}, \mathrm{PC}_{1 \mathrm{c}} ; \mathrm{O}, \mathrm{PC}_{1 \mathrm{a}} ; \mathrm{O}, \mathrm{PC}_{1 \mathrm{~b}}\right)$.

is faster than that of those via a $\mathrm{C}-\mathrm{N}$ link. From these figures, it is also evident that hydrolysis of polyCysH attached 5-FU via the amide link is considerably faster in alkali medium than that in neutral medium.

In general, polymer-controlled drug delivery systems exist medical action only when they release drug units which are fixed to unactive polymeric carrier. In our prepared polymeric drugs, 5-FU is a well-known antitumor agent polyCysH has no antitumor activity. The antitumor activity against Ehrlich ascites 
Table II. Antitumor activity of polyCysH fixed 5-FU against Ehrlich ascites acriconoma in vitro ${ }^{\mathrm{a}}$

\begin{tabular}{rcccccccccccccc}
\hline No. & & $\mathrm{PC}_{1 \mathrm{a}}$ & $\mathrm{PC}_{2 \mathrm{a}}$ & $\mathrm{PC}_{3 \mathbf{a}}$ & $\mathrm{PC}_{1 \mathrm{~b}}$ & $\mathrm{PC}_{2 \mathrm{~b}}$ & $\mathrm{PC}_{3 \mathrm{~b}}$ & $\mathrm{PC}_{1 \mathrm{c}}$ & $\mathrm{PC}^{2} \mathrm{PC}_{3 \mathrm{c}}$ & $\mathrm{PC}_{1 \mathrm{~d}}$ & $\mathrm{PC}_{2 \mathrm{~d}}$ & $\mathrm{PC}_{3 \mathrm{~d}}$ & $5-\mathrm{FU}$ \\
\hline $\begin{array}{c}\text { Concentration } \\
\mathrm{mg} \mathrm{ml}^{-1}\end{array}$ & 25 & 25 & 25 & 20 & 20 & 20 & 30 & 30 & 30 & 35 & 35 & 35 & 15 \\
\hline Inhibition \% & $4 \mathrm{~h}$ & 65 & 60 & 60 & 85 & 76 & 80 & 10 & 8 & 8 & 5 & 5 & 5 & 100 \\
\hline & $24 \mathrm{~h}$ & 100 & 100 & 100 & 100 & 100 & 100 & 40 & 37 & 35 & 37 & 35 & 35 \\
\hline
\end{tabular}

a Tumor cell concentration, $2 \times 10^{6}$ cells/ml; blank test, $1 \% \mathrm{NaCl}$ solution, $4 \mathrm{~h}, 4 \% ; 24 \mathrm{~h}, 15 \%$.

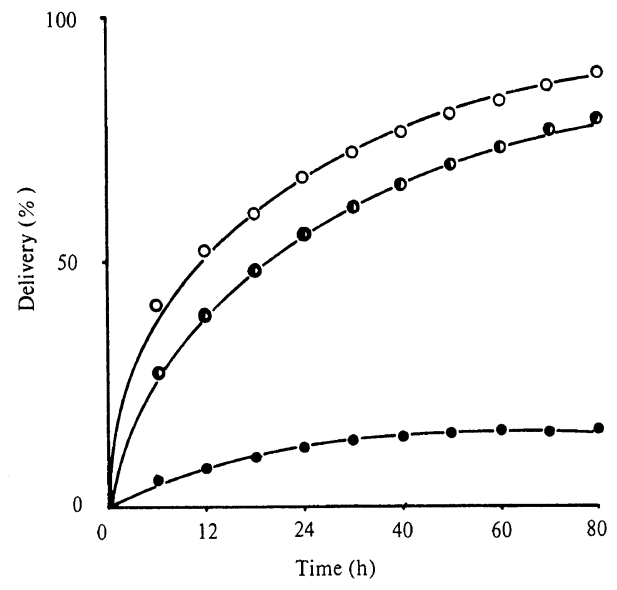

Figure 5. Hydrolytic delivery of 5-FU from polymeric drugs at $37^{\circ} \mathrm{C}$ and $\mathrm{pH} 9\left(\mathrm{O}, \mathrm{PC}_{3 \mathrm{c}} ; \mathrm{O}, \mathrm{PC}_{3 \mathrm{a}} ; \mathrm{O}, \mathrm{PC}_{3 \mathrm{~b}}\right)$.

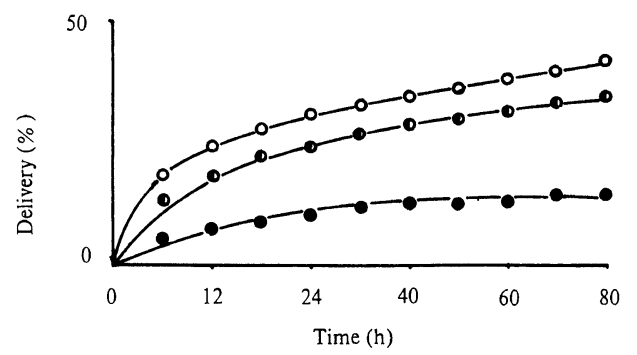

Figure 6. Hydrolytic delivery of 5-FU from polymeric drugs at $37^{\circ} \mathrm{C}$ and $\mathrm{pH} 7\left(\mathrm{O}, \mathrm{PC}_{1 \mathrm{c}} ; \mathrm{O}, \mathrm{PC}_{1 \mathrm{a}} ; \mathrm{O}, \mathrm{PC}_{1 \mathrm{~b}}\right)$.

carcinoma in vitro (Table II) and in vivo (Table III) show that the polymeric drugs attached 5-FU via the amide link provide better antitumor activity than those via the $\mathrm{C}-\mathrm{N}$ link, due to hydrolysis and/or enzymatic release of 5-FU from its polymeric carrier. From Tables
Table III. Antitumor activity of polyCysH fixed 5-FU against Ehrlich ascites carcinoma in vivo

\begin{tabular}{ccccc}
\hline No. & $\begin{array}{c}\text { Dose/ } \\
\mathrm{mg} \mathrm{kg}^{-1}\end{array}$ & $\begin{array}{c}\text { Feeding } \\
\text { times }^{\mathrm{a}}\end{array}$ & $\begin{array}{c}\mathrm{T} / \mathrm{C}^{\mathrm{b}} \\
/ \%\end{array}$ & $\begin{array}{c}\text { Inhibition } \\
\text { ratio/\% }\end{array}$ \\
\hline $\mathrm{PC}_{1 \mathrm{a}}$ & 0.600 & $\mathrm{ip} \times 3$ & 142 & 54 \\
$\mathrm{PC}_{2 \mathrm{a}}$ & 0.650 & $\mathrm{ip} \times 3$ & 142 & 54 \\
$\mathrm{PC}_{3 \mathrm{a}}$ & 0.700 & $\mathrm{ip} \times 3$ & 150 & 57 \\
$\mathrm{PC}_{1 \mathrm{~b}}$ & 0.500 & $\mathrm{ip} \times 3$ & 125 & 64 \\
$\mathrm{PC}_{2 \mathrm{~b}}$ & 0.530 & $\mathrm{ip} \times 3$ & 130 & 61 \\
$\mathrm{PC}_{3 \mathrm{~b}}$ & 0.558 & $\mathrm{ip} \times 3$ & 134 & 59 \\
$\mathrm{PC}_{1 \mathrm{c}}$ & 0.700 & $\mathrm{ip} \times 3$ & 167 & 43 \\
$\mathrm{PC}_{2 \mathrm{c}}$ & 0.750 & $\mathrm{ip} \times 3$ & 167 & 42 \\
$\mathrm{PC}_{3 \mathrm{c}}$ & 0.810 & $\mathrm{ip} \times 3$ & 167 & 42 \\
$\mathrm{PC}_{1 \mathrm{~d}}$ & 0.800 & $\mathrm{ip} \times 3$ & 167 & 45 \\
$\mathrm{PC}_{2 \mathrm{~d}}$ & 0.870 & $\mathrm{ip} \times 3$ & 167 & 42 \\
$\mathrm{PC}_{3 \mathrm{~d}}$ & 0.940 & $\mathrm{ip} \times 3$ & 167 & 43 \\
$5-\mathrm{FU}$ & 0.260 & $\mathrm{ip} \times 3$ & 117 & 84 \\
\hline
\end{tabular}

a The mice were injected on 0,4 , and 8 days, respectively.

b Ratio of median survival of treated mice (T) to that of controlled mice (C).

c Calculated from formula $\left(W_{1}-W_{2}\right) / W_{1}$, where the $W_{1}$ expresses the median increased weight of controlled and the $W_{2}$ that of treated mice.

II and III, it is evident that the inhibition of polymeric drugs on Ehrlich ascites carcinoma shows little influence on the number-average molecular weight of polyCysH. In addition, it is supposed that L-cysteine- $S$ - $\left(\mathrm{CH}_{2}\right)_{x}-5-\mathrm{FU}$ $(x=4,6)$ present some antitumor activity for the result of effective inhibition of polyCysH attached 5-FU via the $\mathrm{C}-\mathrm{N}$ link.

Acknowledgment. The authors wish to express their thanks to Mr. Zongjie Shi (Hubei 
Cancer Institute, Wuhan 430072, P. R. China)

for the test of antitumor activity.

\section{REFERENCES}

1. R. Zhuo, C. Fan, and J. Liao, International Symposium on Polymeric Biomaterials, Preprints, Kunming, PRC, 1988, p 169.

2. F. Yang and R. Zhuo, Chem. J. of Chinese Univ., to be published.

3. C. Zhou and F. Yang, Chem. J. of Chinese Univ., 3(1), 90 (1987).

4. S. Ozaki, H. Mizuno, and H. Mori, Jpn. Kokai, 77-139080; Chem. Abstr., 88, 105403d (1978).

5. Nian'en Zhou, Doctoral Paper of Wuhan University, 1988.

6. A. Gerger, J. Noguchi, and E. Katchalski, J. Am. Chem. Soc., 78, 4483 (1956). 